\title{
The Advantage of Moringa oleifera Powder Addition in Natural Polymer Modified Concrete Mixture
}

\author{
Rr. M. I. Retno Susilorini ${ }^{1}$, Budi Santosa ${ }^{1}$, VG. Sri Rejeki ${ }^{2}$, M.F. Devita Riangsari ${ }^{1}$, Yan's \\ Dianaga Hananta ${ }^{1}$ \\ e-mail: $\underline{\text { susilorini@unika.ac.id }}$ \\ ${ }^{1}$ Department of Civil Engineering, Faculty of Engineering, SCU, \\ ${ }^{2}$ Department of Architecture, Faculty of Architecture and Design, SCU,
}

\begin{abstract}
Polymer modified concrete has become innovative materials to increase durability and sustainability of concrete. It is now important to develop natural polymers that are 'greener' than other chemical polymers. Therefore, this research wants to investigate compressive strength of natural polymer modified concrete added with Moringa oleifera powder, with and without its skin. This research was conducted experimentally in laboratory. There three compositions concrete mixture of several concrete cylinder specimens with dimension $10 \mathrm{~cm} x$ $20 \mathrm{~cm}$ which were cured in plain water for 7, 14, and 28 days. Compressive strength of normal concrete were designed as about f'c $=30 \mathrm{MPa}$. All specimens were tested for compressive strength after curing. This research meets conclusions: (1) Natural polymer modified concrete added by Moringa oleifera with skin specimens have compressive strength $82.85 \%$ compared control specimens; (2) Extreme high compressive strength has achieved by natural polymer modified concrete added by Moringa oleifera without skin specimens that have compressive strength 165,2\% compared control specimens; and (3) Natural polymer made of Moringa oleifera is proven to increase the compressive strength of concrete.
\end{abstract}

Keyword: compressive strength, natural, polymer, modified, concrete, Moringa oleifera.

\section{INTRODUCTION}

Polymer concrete has become alternative materials due to the lack of durability as well as sustainability of ordinary concrete since over than twenty years ago. The next innovation after the polymer concrete was polymer modified concrete that defined as composites made by using polymer, cement and also aggregates, depend on the size of granule by ACI Committee 548 Report (ACI Committee 548, 2003). Some manufactures have developed chemical polymer as addition to concrete mix rather than natural polymer. Therefore, it is important to develop natural polymers that are 'greener' than other chemical polymers.

For many years, seeds of Moringa oleifera well-known as coagulant which contains compound of rhamnosyloxybenzil-isothiocyanate absorbs metallic particles in the water (Sutanto, et. al., 2007). Moringa oleifera also contains glycerol that may accelerate setting of fresh mortar to become harder and stronger (Farobi, et. al., 2012).

Previous researches reported some natural polymers such as Euchema Cottonii and Gracilaria Sp. and (Susilorini et al., 2014a) also Moringa oleifera (Susilorini et 
al., 2014b) to be added in concrete mixture to increase its strength and durability. It should be noted that mortar with addition of Moringa oleifera of $0.2 \%$ of cement weight has good bonding mechanism that increase its compressive strength and durability in plain water, seawater and brackish water (Susilorini et al., 2014b).

According to the situation mentoned above, this research aims to develop the previous research of (Susilorini et al., 2014a), that now Moringa oleifera was added into concrete mixture to have good performance of natural polymer modified concrete. It will investigate the compressive strength of natural polymer modified concrete added with Moringa oleifera powder, with and without its skin (Susilorini et al., 2014c; Hananta and Riangsari, 2016).

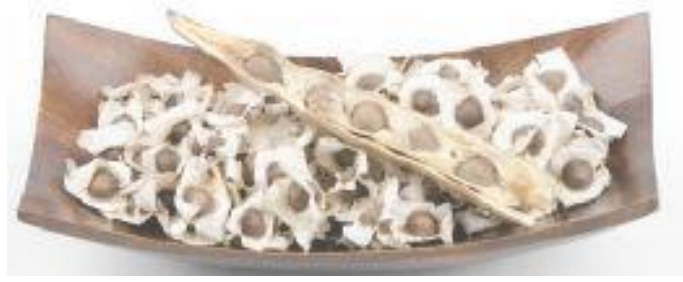

FIGURE 1. M oringa oleifera seeds with skin (http://stseed.weebly.com/uploads/3/1/9/7/3197 0257/s176673169105688152_p2_i1_w500.jpeg)

\section{METHOD OF RESEARCH}

\subsection{Uraian Umum}

This research was conducted experimentally in laboratory. There were several concrete cylinder specimens with dimension $10 \mathrm{~cm}$ x $20 \mathrm{~cm}$ (Figure 2), cured in plain water for 7,14 , and 28 days. Compressive strength of normal concrete were designed as about $\mathrm{f}^{\prime}{ }_{\mathrm{c}}=30 \mathrm{MPa}$. There were three compositions concrete mixture which described by Table 1 . All specimens were tested for compressive strength after curing.
TABLE 1. Concrete Mixture with and without Moringa oleifera (Susilorini, et. al., 2014c; Hananta and Riangsari, 2014)

\begin{tabular}{lccc}
\hline Mix & $\begin{array}{c}\text { \% weight } \\
\text { Moringa } \\
\text { oleifera } \\
\text { of } \\
\text { cement }\end{array}$ & $\begin{array}{c}\text { with / } \\
\text { without } \\
\text { skin }\end{array}$ & $\begin{array}{c}\text { number of } \\
\text { specimens }\end{array}$ \\
\hline K & 0 & N/A & 6 \\
S-K & 0.2 & with & 15 \\
S-TK & 0.2 & withouth & 15 \\
\hline
\end{tabular}

The natural polymer modifier used for the research is Moringa oleifera powder (Figure 3) that were produced by grinding Moringa oleifera seeds, with or without skin.

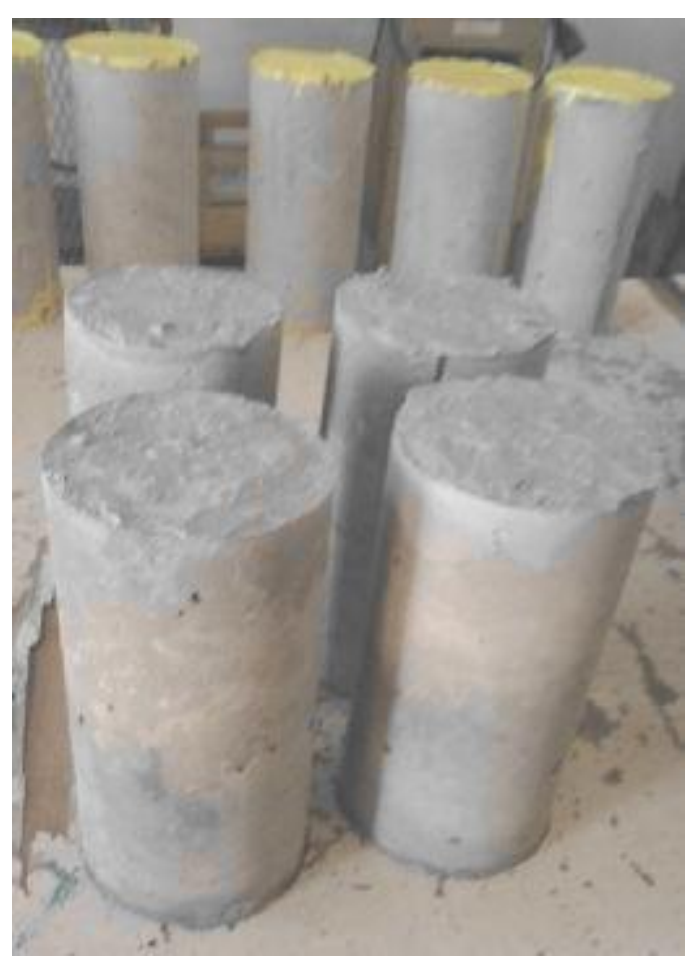

FIGURE 2. Control and natural polymer modified concrete specimens that were ready for compressive test days (Susilorini, et. al., 2014c; Hananta and Riangsari, 2016) 


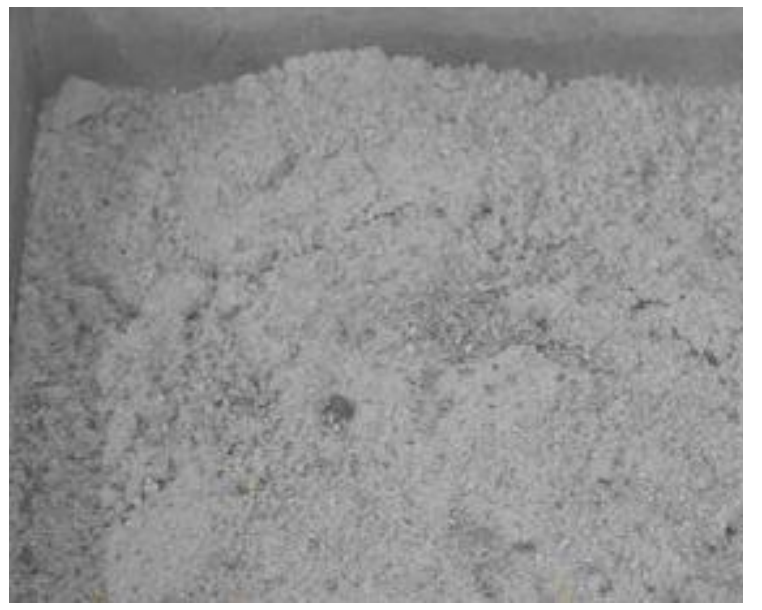

FIGURE 3. Moringa oleifera powder which made by grinding the seeds (Susilorini, et. al., 2014c; Hananta and Riangsari, 2016)

\section{RESULTS AND DISSCUSSION}

Dalam perencanaan khususnya untuk struktur Gedung Fakultas Teknik Sipil Universitas MorenSemarang terdapat beberapa langkah yang perlu dilakukan. Berikut ini adalah langkah-langkahnya yaitu:

The result of compressive strength test has shown by Figure 4, 5, 6. Figure 4 describes that control specimens have gradual increase of compressive strength from age 7 days (K-07) of $22.52 \mathrm{MPa}, 14$ days (K-14) of $26.57 \mathrm{MPa}$, and 28 days (K28) of $31.52 \mathrm{MPa}$.

Specimens of natural polymer modified concrete added by Moringa oleifera with skin has shown higher compressive strength compared to control specimens as described by Figure 5. Those specimens have slight increase of compressive strength from age 7 days (S-K-07) to 14 days (S-K-14) of $28.43 \mathrm{MPa}$ to $33.97 \mathrm{MPa}$, but suddenly achieve higher value of compressive strength at age 28 days ( $\mathrm{S}-\mathrm{K}$ 28) of $48.09 \mathrm{MPa}$.

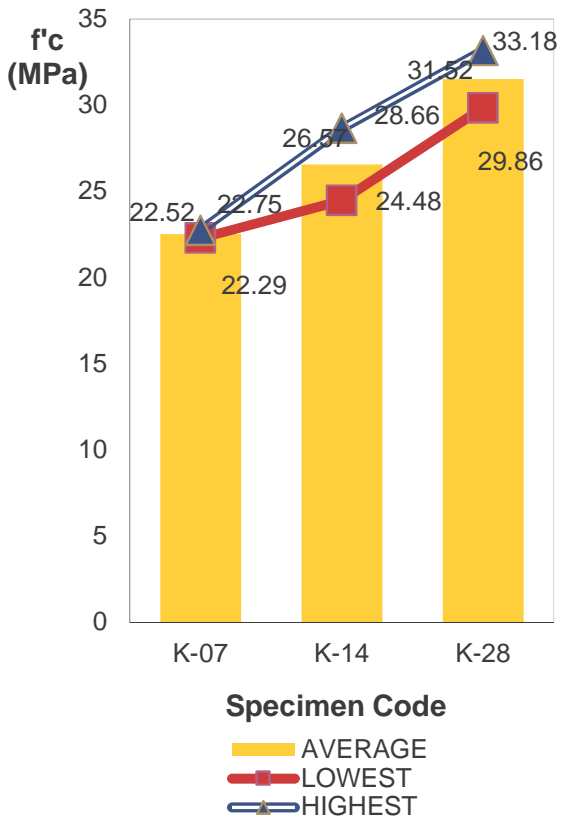

FIGURE 4. Compressive strength of control specimens at ages 7, 14, and 28 days (modified from Susilorini, et. al., 2014c; Hananta and Riangsari, 2016).

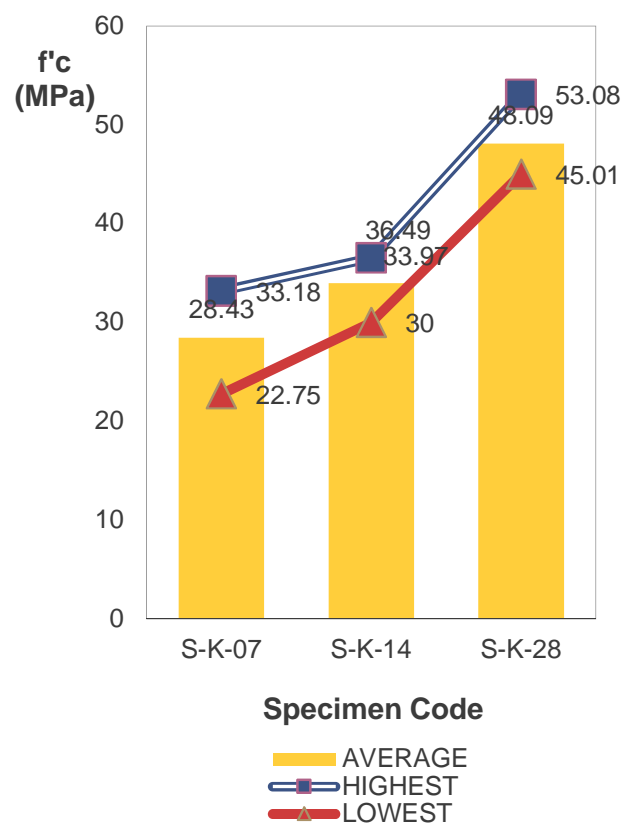

FIGURE 5. Compressive strength of natural polymer modified concrete added by Moringa oleifera with skin specimens at ages 7, 14, and 28 days (modified from Susilorini, et. al., 2014c;

Hananta and Riangsari, 2016) 
It is interesting to find out the result of compressive strength of natural polymer modified concrete added by Moringa oleifera without skin as described by Figure 6 . Those specimens have shown very high compressive strength at age 7 days (S-TK07) of $63.52 \mathrm{MPa}$ and just very slightly reduced at age 14 days (S-TK-14) of 61.62 $\mathrm{MPa}$ and achieve its high final value at age 28 days (S-TK-28) of $64.56 \mathrm{MPa}$.

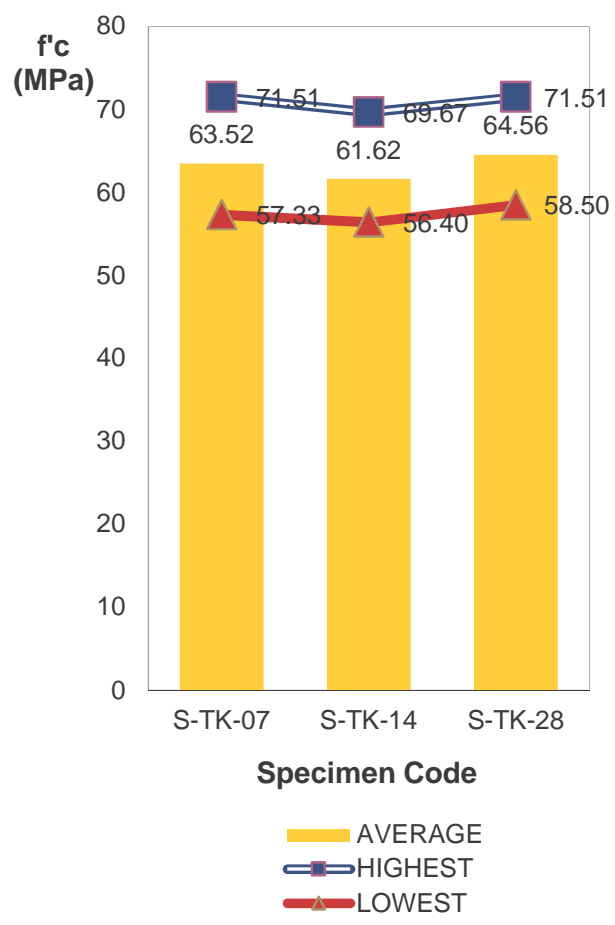

FIGURE 6. Compressive strength of natural polymer modified concrete added by Moringa oleifera without skin specimens at ages 7, 14, and 28 days (modified from Susilorini, et. al., 2014c; Hananta and Riangsari, 2016).

The results noted that natural polymer modified concrete added by Moringa oleifera without skin specimens have great performance compared the ones with skin and even control specimens. It can be understood that specimens with Moringa oleifera skin may not have optimum bonding mechanism due to the presence of wider fiber of the skins. Bonding mechanism will exist in concrete mixture with high workability as provide with the specimens without Moringa oleifera skin.

It is very surprise to find out the result of this research. The distinction of compressive strength between control specimens and specimens with Moringa oleifera skin is $82.85 \%$ that is very high, while compressive strength between control specimens and specimens without Moringa oleifera skin is $165.2 \%$ that is extremely high.

\section{CONCLUSIONS}

This research meets conclusions:

1. Natural polymer modified concrete added by Moringa oleifera with skin specimens have compressive strength $82.85 \%$ compared control specimens

2. Extreme high compressive strength has achieved by natural polymer modified concrete added by Moringa oleifera without skin specimens that have compressive strength $165,2 \%$ compared control specimens

3. Natural polymer made of Moringa oleifera is proven to increase the compressive strength of concrete

\section{ACKNOWLEDGMENTS}

This research was funded by Competency Grant 2014-2016, First Year (2014), Contract No. 052/K6/KL/SP/Penelitian/ 2014, Directorate of Research and Community Service, General Directorate of Research Development Empowerment, Ministry of Research, Technology, and Higher Education, Republic of Indonesia.

\section{REFERENCES}

ACI Committee 548, Polymer-Modified Concrete, ACI 548.3R-03, ACI Committee Report, (1-39) 2003.

Farobie. O, Achmadi, S.S., Darusman, L.K (2012) "Utilization of Glycerol Derived 
from Jatropha's Biodiesel Production as a Cement Grinding Aid" World Academy of Science, Engineering and Technology 6, (791-796).

Hananta, Y. D. Hananta, Riangsari, M. F. V, Kuat Tekan Beton Termodifikasi Alami dengan Bubuk Moringa oleifera (Compressive Strength of Natural Polymer Modified Concrete with Moringa oleifera Powder), Undergraduate Thesis, Soegijapranata Catholic University, 2016.

Susilorini, R. M. I. R. et al. (2014a) 'The advantage of natural polymer modified mortar with seaweed: Green construction material innovation for sustainable concrete', in Procedia Engineering. doi: 10.1016/j.proeng.2014.12.201.

Susilorini, Rr. M. I. R., Hardjasaputra, H., Tudjono, S., Kristianto, Y., Putranto, A., (2014b). "Compressive Strength Optimization of Natural Polymer Modified Mortar with Moringa oleifera in Various Curing Medias" in Proceedings of the 1st International Conference on Engineering Technology and Industrial Aplication (ICETIA), Universitas Muhammadyah Surakarta, Surakarta, pp. 1-4.

Susilorini, Rr. M. I. R., Santosa, B., Rejeki, V.G.S, (2014c). Inovasi Beton Bajik untuk Beton Berkelanjutan (Innovation of Virtuous Concrete for Sustainable Concrete), Final Report, Competency Grant (2014-2016), First Year (2014), Directorate of Research and Community Service, General Directorate of Research Development Empowerment, Ministry of Research, Technology, and Higher Education, Republic of Indonesia. 